Plant Tissue Cult. \& Biotech. 21(2): 189-198, 2011 (December)

$\overline{\text { PTC\&B }}$

\title{
DNA Fingerprinting and Diversity Analysis of BRRI Hybrid Varieties and their Corresponding Parents
}

\author{
M.M. Islam, M.E. Hoque*, S.M.H.A. Rabbi and M.S. Ali \\ Biotechnology Division, Bangladesh Rice Research Institute, Gazipur-1701, Bangladesh \\ Key words: Hybrid rice, Diversity analysis, Microsatellite markers, DNA \\ fingerprinting
}

\begin{abstract}
DNA fingerprinting and genetic diversity of four Bangladesh Rice Research Institute (BRRI) hybrid varieties and their parental lines were carried out. A total of 73 microsatellite markers were tested for screening the genotypes. Among the 73 amplified products, 37\% had polymorphic bands showing 81 alleles. The number of alleles per locus ranged from two (RM10) to eight (RM327), where average allele number was 4.333. The Polymorphism Information Contents (PIC) lied between 0.337 (RM10) and 0.852 (RM327). RM327 was the most robust marker providing the highest PIC value (0.852). Pair-wise genetic dissimilarity coefficient interaction showed that BRRI hybrids two was the most genetically distant from each other whereas BRRI hybrids one, three, four and their respective parents were very close. Cluster analysis based on Dice's similarity coefficient UPGMA system grouped BRRI hybrid and their parental lines into four major clusters at 0.41 cut off similarity coefficient. Four BRRI hybrid varieties grouped into four distinct clusters along with their component lines indicating their genetic closeness.
\end{abstract}

\section{Introduction}

Rice is the staple food of Bangladesh, contributing more than $75 \%$ of the total dietary intake of its population. The annual rice production of the country was 10.0 million tons in 1970-71 which increased to 32.0 million tons in 2009-2010 through the development and use of HYVs on semi-dwarf plant type. However, by the year 2020, the population will be around 180 million and the country will have to produce 36.0 million tons to sustain self sufficiency in food as well as food security. With the plateauing trend in the yield of HYVs over the last decade, and no scope for horizontal expansion of rice area, achieving the above rice production target is not going to be an easy task. Under

*Corresponding author.<hoqueh2003@yahoo.com>. 
such a situation, resorting to development and adaption of yield enhancing technologies appear to be the only logical and practicable solution to the potential food problem. Among various technological options, the exploitation of hybrid vigor is recognized as readily available, practically adaptable, and a feasible option for meeting the increased demand for rice in Bangladesh. Usually hybrid rice gives 15 - 20\% higher yield as compared to the best semi-dwarf inbred cultivar (Yuan et al. 1994).

The identification of rice cultivars and lines and determination of their genetic relations are very important for plant improvement program, variety registration system, DUS (distinctness, uniformity and stability) testing and for the protection of plant variety and breeders' rights (Ichii et al. 2003, Kwon et al. 2005). Therefore, clear-cut identification of elite crop varieties and hybrids is essential for protection and prevention of unauthorized commercial use (Nandakumr et al. 2004). Conventional characterization of hybrids based on specific morphological and agronomic data is time consuming, restricted to a few DNA characteristics and influenced by environmental condition. In contrast, DNA-based markers are highly heritable, available in high numbers, and exhibit enough polymorphism; hence they can be used to discriminate closely related genotypes of a plant (Kumar 1999, Yashitola et al. 2002, Wang et al. 2005). For these reasons, DNA fingerprinting for cultivar or varietal identification has become an important tool in plant breeding and germplasm management (Wang et al. 2005). Therefore, the present investigation was carried out with the objectives of assessing genetic diversity and DNA fingerprinting of four BRRI hybrid varieties and their corresponding parents using SSR markers across chromosomes 1-12.

\section{Materials and Methods}

Sixteen genotypes, including four cytoplasmic male-sterile (CMS) lines (A line), four restorer lines ( $\mathrm{R}$ line), four maintainer lines (B line) and four of their hybrid combinations were $\left(\mathrm{F}_{1 \mathrm{~s}}\right)$ used for the present study (Table 1$)$. Seeds were collected from BRRI.

Fresh leaf samples of 21-day-old rice seedlings were used as the source of genomic DNA. DNA was isolated following CTAB method with minor modifications described by Zheng et al. (1995). At first leaf tissue were cut into small pieces, homogenized and digested with extraction buffer (1M Tris, $0.5 \mathrm{M}$ EDTA, $5 \mathrm{M} \mathrm{NaCl}$ and $20 \% \mathrm{SDS}, \mathrm{pH} 8.0$ ). After incubation for $20 \mathrm{~min}$ at $65^{\circ} \mathrm{C}$ with intermittent swirling, the mixture was emulsified with chloroform: IAA mix (24: 1 mixture of chloroform and isoamyl alcohol). After centrifugation, the upper aqueous layer was removed into a different tube and cold ethanol was added. 
After centrifugation a small pellet was visible. The pellets were then washed with $70 \%$ ethanol, dried by a concentrator and resuspended in an appropriate volume of TE buffer (1M Tris, 0.5M EDTA, pH 8.0). DNA quality was checked by agarose gel electrophoresis with lambda DNA (50 ng/ $\mu$ l) and quantification was done using a spectrophotometer (Nano drop 1000 V3.6, USA).

Table 1. Four BRRI hybrids and their corresponding parents.

\begin{tabular}{cllc}
\hline Sl.No. & Genotype & Types of lines & Origin \\
\hline 1 & *BHR1A line & CMS & BRRI \\
2 & BHR1B " & Maintainer & $"$ \\
3 & BHR1R " BHR1F1 & Restorer & $"$ \\
4 & BHR1F1 & Hybrid & $"$ \\
5 & BHR2A line & CMS & $"$ \\
6 & BHR2B " & Maintainer & $"$ \\
7 & BHR2R " & Restorer & $"$ \\
8 & BHR2F1 & Hybrid & $"$ \\
9 & BHR3A line & CMS & $"$ \\
10 & BHR3B " & Maintainer & $"$ \\
11 & BHR3R " & Restorer & $"$ \\
12 & BHR3F1 & Hybrid & $"$ \\
13 & BHR4A line & CMS & $"$ \\
14 & BHR4B " & Maintainer & $"$ \\
15 & BHR4R $"$ & Restorer & \\
16 & BHR4F1 & Hybrid & \\
\hline
\end{tabular}

${ }^{*} \mathrm{BHR}=\mathrm{BRRI}$ hybrid rice.

PCR was carried out in $10 \mu \mathrm{l}$ reactions volume containing $1 \mu \mathrm{l}$ of $\mathrm{MgCl}_{2}$ free $10 \times$ PCR buffer with $\left(\mathrm{NH}_{4}\right)_{2} \mathrm{SO}_{4}, 1.2 \mu \mathrm{l}$ of $25 \mathrm{mM} \mathrm{MgCl} 2,0.2 \mu \mathrm{l}$ of $10 \mathrm{mM}$ dNTPs, $0.2 \mu \mathrm{l}$ of $5 \mathrm{U} / \mu \mathrm{l}$ Taq DNA polymerase, $0.5 \mu \mathrm{l}$ of $10 \mu \mathrm{M}$ forward and reverse primers (Promega corporation, USA) and $3 \mu \mathrm{l}$ (10 ng) of DNA using a 96 well thermal cycler. Amplification were carried out in a thermal cycler (G-strom, GSI, England) with the following program: $94^{\circ} \mathrm{C}$ for $5 \mathrm{~min}$ (initial denaturation) followed by 35 cycles of $94^{\circ} \mathrm{C}$ for $1 \mathrm{~min}$ (denaturation), $55^{\circ} \mathrm{C}$ for $1 \mathrm{~min}$ (annealing), $72^{\circ} \mathrm{C}$ for $2 \mathrm{~min}$ (extension) with a final extension for $7 \mathrm{~min}$ at $72^{\circ} \mathrm{C}$. The annealing temperatures were adjusted based on the specific requirements of each primer combination. After amplification, PCR products were mixed with gel loading dye (bromophenol blue, xylene cyanol and sucrose), and electrophoresed using vertical polyacrylamide gels (8\% denatured polyacrylamide gel containing 19:1 acrylamide: bhisacrylamide) for manual genotyping. Four $\mu \mathrm{l}$ of the amplification products were resolved by running the 
gel in $1 \times$ TBE buffer for 1.5 to $2.5 \mathrm{hrs}$ (depending on the allele size) at around 90 volts and $500 \mathrm{~mA}$ electricity (CBS scientific, USA). The gels were stained in $1 \mu \mathrm{g} / \mathrm{ml}$ ethidium bromide and documented using UVPRO (Uvipro Platinum, EU) gel documentation unit. A total of 27 SSR markers (distributed across the 12 chromosomes) with clear amplifications were selected for genetic diversity analysis of four BRRI hybrids and their component lines.

Size for each amplified allele was measured in base pair using Alpha-Ease FC 5.0 software (Alpha Innotech, USA). The summary statistics including the number of alleles per locus, major allele frequency, gene diversity, Polymorphism Information Content (PIC) values were determined using Power Marker version 3.25 (Liu and Muse 2005). The allele frequency data from Power Marker was used to export in binary format (allele presence $=1$ and allele absence $=0$ ) for analysis with NTSYS-pc version 2.1 (Rohlf 2002). The Excel file containing the binary data was imported into NT-Edit of NTSYS-pc. The similarity matrix was used to calculate similarity as DICE co-efficient using SIMQUAL sub routine in SIMILARITY routine. The resultant similarity matrix was employed to construct dendrograms using Sequential Agglomerative Hierarchical Nesting (SAHN) based Unweighted Pair Group Method with Arithmetic means (UPGMA).

\section{Results and Discussion}

Four BRRI hybrid rice varieties and their parental lines were assessed for genetic variability using DNA fingerprinting technology. In the present study, 73 microsatellite markers were used and among them 27 primers found polymorphic. A total of 81 alleles were detected at the loci of 27 microsatellite markers across the four BRRI hybrids and their parental lines. The highest amplicon size was produced by RM 566 (280 bp) and the lowest by RM1 (95 bp). The highest range of band sizes was found in RM566 (260 - 280) followed by RM444 (170 - 250) and RM122 (225 - 240), respectively (Table 2). The number of alleles per locus ranged from 2 (RM10) to 8 (RM327) with an average of 4.333 alleles across the 27 loci. The frequency of the most common allele at each locus ranged from $15.63 \%$ (RM327) to $68.75 \%$ (RM10 and RM519). On an average, $45.14 \%$ of the four BRRI hybrids and their component lines shared a common major allele at any given locus. Polymorphism Information Content (PIC) values ranged from 0.3374 to 0.8522 with an average of 0.6158 . The highest PIC value (0.8522) was obtained for RM327 followed by RM264 (0.8308), RM222 (0.8308) and RM 566 (0.7055), respectively (Table 2). Therefore, depending upon the PIC values it can be concluded that among the 73 marker tested, RM327, RM264, 
RM222 and RM566 marker were found to be suitable for distinguishing four BRRI hybrids and their parental lines (Table 2).

Table 2. Data on the number of alleles, allele size range, major frequency allele and polymorphism information content (PIC) for 27 microsatellite markers.

\begin{tabular}{|c|c|c|c|c|c|c|c|}
\hline Marker & $\begin{array}{c}\text { Chr. } \\
\text { no. }\end{array}$ & $\begin{array}{c}\text { Position } \\
(\mathrm{Mbp})\end{array}$ & $\begin{array}{c}\text { Allele } \\
\text { no. }\end{array}$ & $\begin{array}{c}\text { Size } \\
\text { range }\end{array}$ & $\begin{array}{l}\text { Major } \\
\text { allele }\end{array}$ & $\begin{array}{c}\text { Major allele } \\
\text { frequency }\end{array}$ & PIC \\
\hline RM1 & 1 & 39.22 & 4.0000 & $95-120$ & 120 & 0.3438 & 0.6579 \\
\hline RM237 & 1 & 35.27 & 4.0000 & $125-137$ & 130 & 0.3438 & 0.6579 \\
\hline RM128 & 1 & 19.16 & 3.0000 & 154-161 & 154 & 0.5938 & 0.4962 \\
\hline RM211 & 2 & 3.66 & 4.0000 & $148-155$ & 148,155 & 0.3438 & 0.6579 \\
\hline RM71 & 2 & 3.66 & 4.0000 & $123-149$ & 149 & 0.4375 & 0.6474 \\
\hline RM327 & 2 & 17.16 & 8.0000 & $205-216$ & 207,209 & 0.1563 & 0.8522 \\
\hline RM7 & 3 & 64.00 & 3.0000 & $160-176$ & 171 & 0.5000 & 0.5304 \\
\hline RM564 & 3 & 0.17 & 4.0000 & $200-210$ & 208 & 0.5000 & 0.6019 \\
\hline RM119 & 4 & 21.22 & 4.0000 & $163-175$ & 170 & 0.6563 & 0.4902 \\
\hline RM169 & 5 & 64.00 & 5.0000 & $155-200$ & 199 & 0.3438 & 0.7000 \\
\hline RM122 & 5 & 1.47 & 4.0000 & $225-240$ & 230 & 0.5000 & 0.6019 \\
\hline RM314 & 6 & 8.50 & 5.0000 & $114-126$ & 117 & 0.3438 & 0.7000 \\
\hline RM541 & 6 & 19.21 & 4.0000 & $180-192$ & 182 & 0.5625 & 0.5505 \\
\hline RM217 & 6 & 35.53 & 5.0000 & $125-157$ & 155 & 0.4063 & 0.6897 \\
\hline RM10 & 7 & 79.10 & 2.0000 & $167-170$ & 170 & 0.6875 & 0.3374 \\
\hline RM11 & 7 & 19.25 & 4.0000 & $130-158$ & 149 & 0.6563 & 0.4902 \\
\hline RM264 & 8 & 32.72 & 7.0000 & $156-178$ & 170 & 0.1875 & 0.8308 \\
\hline RM126 & 8 & 26.66 & 4.0000 & $164-170$ & 164 & 0.5000 & 0.6194 \\
\hline RM566 & 9 & & 5.0000 & $260-280$ & 265 & 0.4063 & 0.7055 \\
\hline RM219 & 9 & 2.98 & 4.0000 & $220-240$ & 220 & 0.5625 & 0.5505 \\
\hline RM215 & 9 & 32.62 & 4.0000 & $149-153$ & 149 & 0.5938 & 0.5472 \\
\hline RM444 & 9 & 5.9 & 4.0000 & $170-250$ & 175 & 0.3438 & 0.6579 \\
\hline RM222 & 10 & 2.88 & 7.0000 & $208-220$ & $\begin{array}{l}212,215 \\
214,217\end{array}$ & 0.1875 & 0.8308 \\
\hline RM216 & 10 & 5.1 & 4.0000 & $135-146$ & 135 & 0.5938 & 0.5472 \\
\hline RM202 & 11 & & 4.0000 & $158-180$ & 180 & 0.3438 & 0.6579 \\
\hline RM224 & 11 & 30.53 & 4.0000 & $140-160$ & 160 & 0.4063 & 0.5861 \\
\hline RM519 & 12 & 19.9 & 3.0000 & $124-140$ & 140 & 0.6875 & 0.4312 \\
\hline Mean & & & 4.3333 & & & 0.4514 & 0.6158 \\
\hline
\end{tabular}

DNA profile of markers RM327 and RM264 for all 16 genotypes of BRRI hybrids and their parental lines are shown in Figs 1 and 2, respectively. Similar results were observed in previous fingerprinting and diversity studies, having 1- 8 alleles with an average of 4.58 alleles for various classes of microsatellite (Siwach et al. 2004) and also 3 to 9 alleles, with an average of 4.53 alleles per locus for 30 microsatellite markers (Hossain et al. 2007). In another study, Rahman et al. (2009) found an average of 6.33 alleles per locus in rice using 
Bangladeshi high yielding varieties, local cultivars and wild races. We can compare our frequency for most common alleles found by Thomson et al. (2007) which ranged from 21 (RM154) to 73\% (RM214). The PIC values of the present study are comparable to other two previous reports in rice viz. 0.20 - 0.90 with an average of 0.56 (Jain et al. 2003) and 0.30 - 0.84 with an average of 0.58 (Hossain et al. 2007).

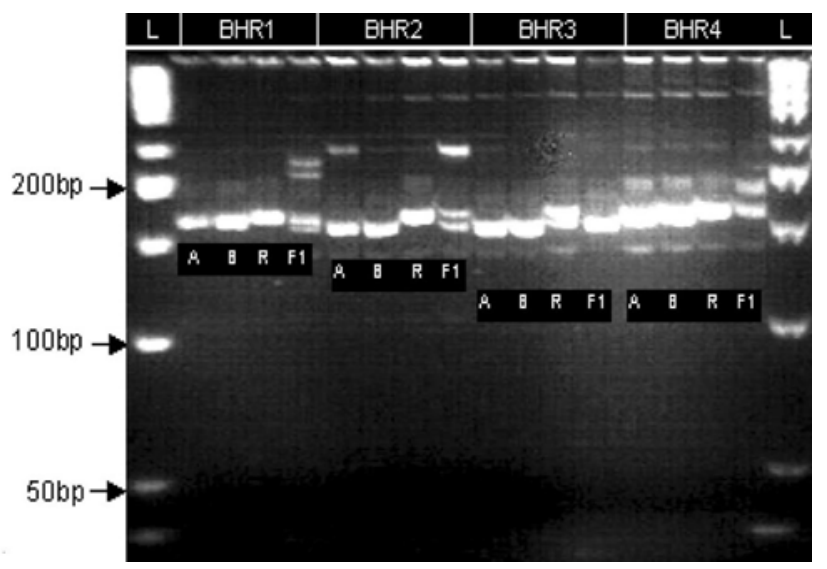

Fig. 1. DNA profile of the four BRRI hybrids and their components lines with the SSR marker RM327.

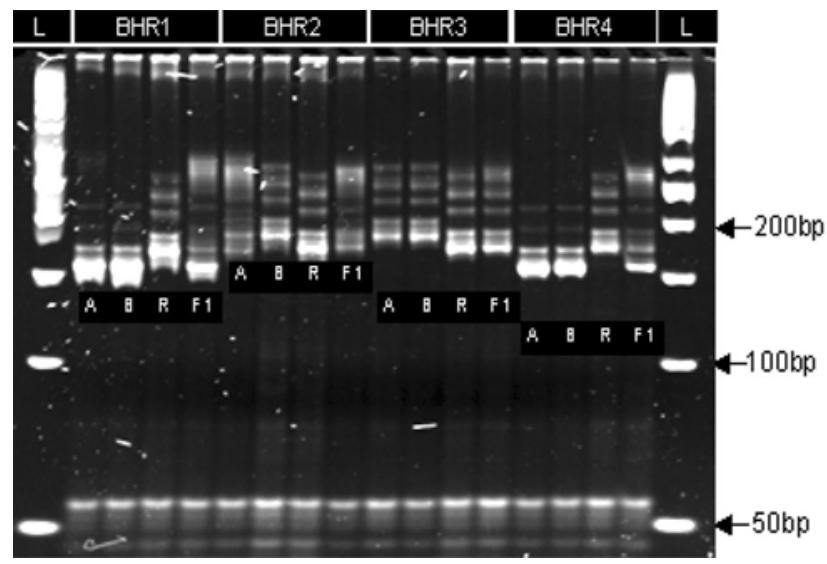

Fig. 2. DNA profile of the four BRRI hybrids and their components lines with the SSR marker RM264.

Pair-wise genetic dissimilarity coefficient was measured among the test entries. The highest and lowest dissimilarity values were 0.8889 and 0.1844 , respectively (Table 3) which was found in several pair interactions. Pair-wise genetic dissimilarity coefficient interaction showed that BRRI hybrid two was the most genetically distant from each other whereas BRRI hybrid one, three, four and their respective parents were very close (Table 3 ). To get maximum 


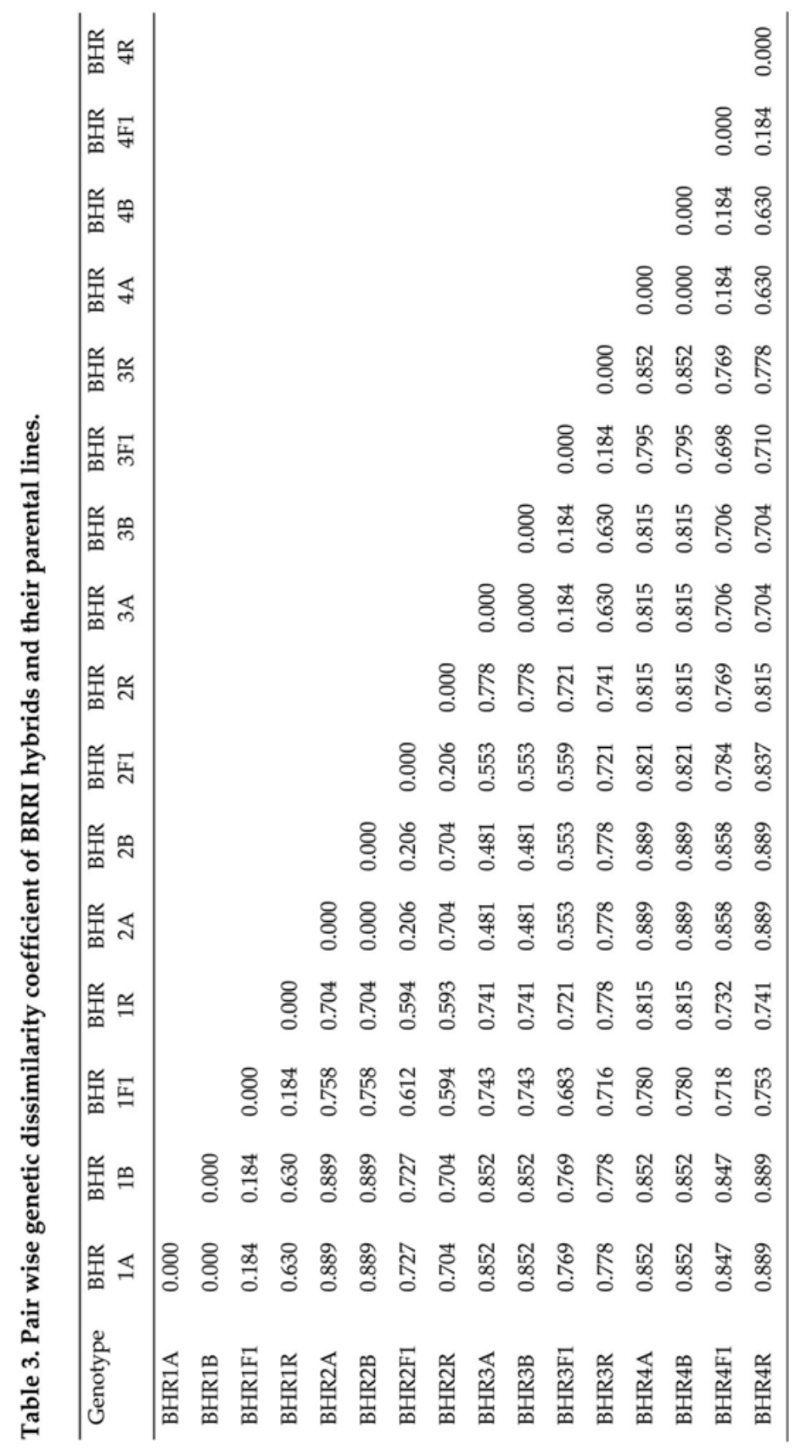


heterosis, diverged genotypes should be exploited in any hybrid breeding program. But from the present study it reveals that BRRI hybrids did not show highest heterosis due to not using the distant parents. However, on the basis of analyzed data presented in the Table 3, it can be concluded that hybrids having highest heterosis could be obtained if the divergent parents (BHR1A, BHR2A, BHR2B, BHR4A, BHR4B BHR4R) were used for crossing. Therefore, in future, attempts should be taken to make crosses between the most diverse parents to get hybrid varieties with highest heterosis. Cluster analysis was used to group

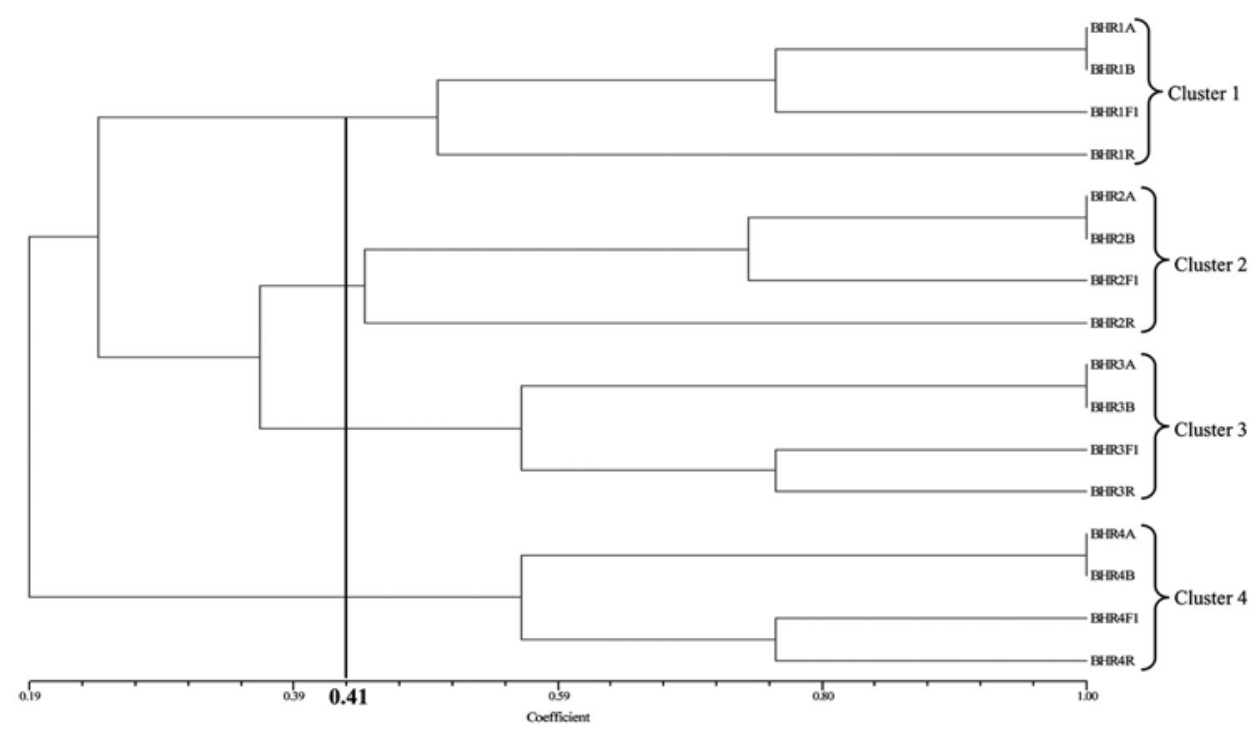

Fig. 3. A UPGMA cluster dendogram showing the genetic relationship among four BRRI hybrids and their component lines based on allele detected by 27 microsatellite markers.

the BRRI hybrid genotypes and their parents to construct a dendogram. UPGMA based dendogram obtained from the binary data deduced from the DNA profiles of the analyzed samples. A total of four distinct groups resulted out of analysis of pooled SSR marker data at a cut-off similarity coefficient 0.41 (Fig. 3), UPGMA clustering system of the four hybrids and their parental lines revealed that, they have very strong parental linkage (Haque et al. 2002 and Kabir et al. 1994). This fingerprinting data will identify the genotypes very easily and the information generated from the study could be used in further molecular characterization with other hybrid genotypes. In this study, the larger range of similarity values for genotypes indicated by microsatellite markers provides greater confidence for the assessments of genetic diversity and relationships, which can be used in future hybrid breeding programs. 


\section{Acknowledgements}

This research work was funded by "Strengthening and Capacity Building of Biotechnology Laboratory in BRRI" Project, Ministry of Agriculture, Government of the People's Republic of Bangladesh.

\section{References}

Haque E, Rahman MA, Hossain MA, Salam MA and Haque M (2002) Genetic composition of BRRI varieties: II. BRRI dhan27- BRRI dhan41 and BRRI hybrid dhan1. Bangladesh Rice J. 11: 53-63.

Hossain MZ, Rasul MG, Ali MS, Iftekharuddaula KM and Mian MAK (2007) Molecualar characterization and genetic diversity in fine grain and aromatic landraces of rice using microsatellite markers. Bangladesh J. Genet. Pl. Breed. 20(2): 01-10.

Ichii M, Hong DL, Ohara Y, Zhao CM and Taketa S (2003) Characterization of CMS and maintainer lines in indica rice (Oryza sativa L.) based on RAPD marker analysis. Euphytica 129: 249-252.

Jain S, Mitchell SE, Jain RK, Kresovich S and McCouch SR (2003) DNA fingerprinting and phylogenetic analysis of Indian aromatic high quality rice germplasm using panels of fluorescent-labeled microsatellite markers. In: Advance in Rice Genetics, Khush GS, Brar DS and Hardy B (Eds), IRRI, Philippine, pp. 162-165.

Kabir MM, Sarker HC, Salam MA, Hoque M and Miah NM (1994) Genetic composition of improved rice varieties in Bangladesh. Bangladesh Rice J. 5(1\&2): 95- 110.

Kumar LS (1999) DNA markers in plant improvement: an overview. Biotecnol. Adv. 17: 143-182.

Kwon YS, Lee JM, Yi GB, Yi GB, Yi Sl, Kim KM, Soh EH, Bae KM, Park EK, Song IH and Kim BD (2005) Use of SSR markers to complement tests of distinctiveness, uniformity and stability (DUS) of pepper (Capsicum annuum L.) varieties. Mol. Cells. 19: $428-435$.

Liu, K, and Muse S V ( 2005) PowerMarker: Integrated analysis environment for genetic marker data. Bioinformatics. 21: 2128-2129.

Nandakumr N, Singh A, Sharma K, Mohapara RK, Prabhu TKV and Zaman FU (2004) Molecular fingerprinting of hybrids and assessment of genetic purity of hybrid seeds in rice using microsatellite markers. Euphytica 136: 257-264.

Rahman MS, Molla MR, Alam MS and Rahman L (2009) DNA fingerprinting of rice (Oryza sativa L.) cultivars using microsatellite markers. Australian Journal of crop Science 3 (3): 122-128.

Rohlf F (2002) NTSYS-pc: Numerical taxonomy and multivariate analysis system, $2.1 \mathrm{edn}$. Department of Ecology and Evolution, State University of NY, Stony Brook.

Siwach P, Jain S, Saini N, Chowdhury VK and Jain RK (2004) Allelic diversity among Basmati and Non-Basmati long grain indica rice varieties using microsatellite mrkers. J. Pl.. Biochem. Biotech. 13: 25-32. 
Thomson MJ, Septiningsih EM, Suwardjo F, Santose TJ, Sililonga TS and McCouch SR (2007) Genetic diversity analysis of traditional and improved Indonesia rice (O. Sativa L.) germplasm using microsatellite markers. Theor. Appl. Genet. 114 : 559-568.

Wang Y, Xue Y and Li J (2005) Towards molecular breeding and improvement of rice in China. Trends plant Sci. 10: 610-614.

Yashitola J, Thirumurgan T, Sundaram RM, Naseerullah MK, Ramesha MS, Sarma NP and Sonti RV (2002) Assessment of purity of rice hybrid using microsatellite and STS markers. Crop Sci. 42: 1369-1373.

Yuan LP, Yang ZY and Yang JB (1994) Hybrid rice in China. In: Hybrid rice technology, new developments and future prospects Virmani S S (Ed.), IRRI, Philippines, pp.143147.

Zheng KL, Huang N, Bennet J and Khush GS (1995) PCR - based marker assisted selection in rice breeding. IRRI Discussion Paper Series no. 12. 